\title{
Professional Coach: The Link between Science and Media
}

\author{
Boris ,BLUMENSTEIN ${ }^{1} \bullet$ Iris, $\mathrm{ORBACH}^{2}$
}

Q port science and sport media give special attention to professional

$\checkmark$ coaches from individual and team sport. However, there is not a lot of knowledge on those two approaches: Science and media. Therefore, the purpose of this article was to present sport science approach oriented on research, and sport media approach based on description of "coach life stories". In this article we describe five cases of individual and team coaches. Similarities and difference in these two approaches are discussed.

Key words: Science, Media, Professional Coach

\footnotetext{
${ }^{1}$ Ribstein Center for Sport Medicine Sciences and Research, Wingate Institute for Physical Education and Sport, Israel

${ }^{2}$ Givat Washington Academic College, Israel
} 


\section{Professional Coach: The Link between Science and Media}

Modern competitive sport, including Olympic Games, is considered as a professional area, being affected by science approaches and popular media coverage. When analyzing athlete's achievement it can be seen that the coach takes an essential role in helping athletes to improve and achieve success. We can learn about the coaches' approach from the sport media and the sport science. The sport media gives athletes and coaches' achievement and their life stories a place in the sport coverage. Moreover, in sport science many articles can be found focusing on athletes and coaches characteristics.

First attempts to understand professional model of coaching focused on the topic of sport personology and were accumulated until the mid-1980s' (Cratty, 1973; Martens, 1981; Ogilvie, 1968; Vealey, 1989, 1992). In later studies which focused on the personality characteristics of the coach, it was found that the coach should possess leadership characteristics and the ability to build a positive relationship with the athletes, especially in team sports (Schneider \& Stier, 2008). In addition to specific type of personality, Bloom (2002) suggested that special knowledge is a critical factor for the coach to be successful. Experts (Gilbert, Cote, \& Mallett, 2006; Gilbert \& Trudel, 2004) recommended that coach's knowledge should include areas such as knowledge of the sport (e.g., rules, facilities), knowledge of the people in the specific sport (e.g., athletes, coaches, parents), and knowledge of sport sciences as related to the sport (e.g., technique, methodology, psychology). Later, Smith and Smoll (2005) found that coach's knowledge (general and sport specific) is related to coach's skills: Planning skills, the ability to increase the athlete's motivation, and the ability to analyze results and to provide the athletes with an effective positive and negative feedback (Escarti \& Guzman, 1999; Martens, 2004).

Sport scientists around the world (Scotland: Hendry \&Love, 1996; Australia: Olderhove, 1996; Japan: Yamaguchi, 1996) and international organizations (Coaching Association of Canada, 2005; European Coaching Council, 2006; Sports Coach UK, 2007) have attempted to develop coach's profile, educational programs, and standards for coaches. What knowledge and skills are needed to become a high performance coach? What characterize these top level coaches based on media coverage in real life situations?

\section{Professional coach in science}

Expert coach works with experienced athletes who achieve international levels and are more independent than less experienced athletes. High achievement, medals in international events and competitions, including Olympic Games, 
are the main goals of the expert coach. This orientation has a major effect on the expert coach's profile. The science approach of this article is based on a research project which focused on professional profile of the individual coach (IC) and the team coach (TC) (Blumenstein \& Orbach, 2010; Blumenstein, Orbach, Bar-Eli, Dreshman, \& Weinstein, 2012). The major tool to describe and compare between the expert coaches was a self-report questionnaire which focuses on three areas: Personality characteristics, knowledge, and skills. In this article we described elements of the profile of expert coaches who worked with athletes that reached first-third places or finals in Olympic Games and World's/ European championship.

In our study we found that the skills of the expert coach are very practical and goal minded. They help to achieve and win (Martens, 2004). Therefore, the expert coach is critical regarding his/her athlete's achievements and his/ her qualities as a coach. The expert coach is in a search for innovative methods for achievements and ways to perfect his knowledge (Blumenstein \& Orbach, 2010; Blumenstein, Orbach, Bar-Eli, Dreshman, \& Weinstein, 2012; Martens, 2004). Moreover according to our research, he is characterized with personal perfectionism and self-criticism.

We found that the demands of being a team sport coach or an individual sport coach has its own skill specialization/requirements. Both coaches' groups (IC and TC) had special knowledge in theory and methodology of sport training, technical and tactical preparations, knowledge and experience in managing and organizing practice and competition. The typical skills of the IC were skills that are related to technique of the movement, performance, knowledge in biomechanics, and recovery ways after competitive stress, all help to achieve best athlete's result. However, in the TC group we found skills which were significantly different than the IC and are related to people communication, relationship, leadership (Henschen \& Cook, 2003), and experience in psychological preparation (Blumenstein \& Orbach, 2010). Those skills are crucial to the team coach since s/he needs to develop relationship with different populations such as athletes, staff, media, officials, and others.

Moreover, we found that expert coach does not hesitate to take responsibility for losses. This can be illustrated and supported by the sport media. For example, after the non successful performance during the 2010 FIFA World Cup, Italy national soccer coach, Marcello Lippi, said the following: "I will take full responsibility for this. Honestly, I was sure the team will do better" (Mukoka, 2010). This and similar citations published in the popular sport media have demonstrated how scientific findings is being reflected in real-life settings. 


\section{Professional coach in sport media}

The media reflect the real-life settings usually by basing its material on observations and interviews ('what you see and what you hear'). Below, we present several media illustrations on the best team and individual coaches which reflect this link between science and media. Our research described expert coaches as a unique group of people with high professional standards. It will be interesting to understand how media describe coaches' ability to cooperate and bring elite athletes to the highest level of performance.

Case 1: One of the best NBA' coach, Phil Jackson (Chicago Bulls, 19891998; LA Lakers, 1999-2004, 2005-2011), worked with NBA's stars such as Michael Jordan, Shaquille O'Neal, Scottie Pippen, Kobe Bryant and others. The sport media described Jackson as a coach that applied Native American spiritual practices which combined with eastern philosophy, therefore earned the nickname "Zen Master". He is the author of several books which described his teams and his basketball strategies. Jackson is also a recipient of the state of North Dakota's Roughrider Award. In 1996 Jackson was named one of the 10 greatest coaches in the NBA league history. In 2007 Jackson was introduced into the Basketball Hall of Fame (Press Release, 2007).

Jackson's coaching approach focused on adaptability. According to media interpretation he learned to understand the value of each player as a part of the whole and how overdependence of anyone player can cause a team to fall apart. Jackson did something that many coaches have struggled to do - build a consistently winning team around a megastar. Although Jackson referred to Bryant as an "uncoachable" player, Bryant appreciated Jackson's approach and was cited that the team would be "drastically different" without Jackson's steady, cerebral present on the sideline (Jackson, Wikipedia). Jackson chose a balance between individual and team goals and demanded that player must perform for team or team performs for stars. For success it is important that the players will accept this philosophy. One of Jackson players', Horace Grant, told the "New York times" (December 17, 1988) "it was like we were let out of a cage. We won the game because we were so relaxed" (Jackson, nba.com).

Jackson was named by the media as the master of mind games although the reason for this nickname was an observation by the media that was led out of proportion. In the 2001 NBA Finals against the Philadelphia 76ers, Jackson had Tyronn Lue, a player on the Lakers team who was comparable in size and height to Sixers star Allen Iverson, wear a sock on his arm during Lakers practice. The purpose was to simulate Iverson's use of a compression arm sleeve as part of his regular game time attire. Philadelphia media considered this to be a mind 
game tactic of Jackson's, but the main idea was to simulate what a game against Iverson is like (Reheuser, 2001).

Case 2: Another example from professional sport is Jose Mourinho, one of the best soccer coaches and the past manager of Real Madrid in the Spanish La Liga, and the current manager of Chelsea Football Club in the England Premier League. He has the nickname "The Special One," a self-proclaimed title which was later taken up by the British media (The Daily Telegraph, 2008). He was named the world's best football manager by the International Federation of Football History and Statistics (IFFHS) for both the 2004-05 and 2005-06 seasons. Mourinho's excellent achievements in soccer have attracted positive media coverage which created his current respectful profile in the eyes of the fans. For example, the media describes his study in sport science in the Technical University of Lisbon and his cooperation with the Englishman Sir Bobby Robson, in Lisbon club Sporting Clube de Portugal. The two complemented each other: Robson favored an attacking style, while Mourinho covered defensive options. Moreover, Mourinho prefers planning and training which combined with Robson's direct man-management. Mourinho said that "one of the most important things I learnt from Bobby Robson is that when you win, you shouldn't assume you are the team, and when you lose, you shouldn't think you are rubbish" (Hawkey, 2004).

The sports media covers Mourinho's coaching style very closely. He is defined by the media as a coach with an independent coaching style. He sought to redefine the role of coach in football by mixing coaching theory with motivational and psychological techniques (Cowley, 2005). Mourinho has characterized himself as a relaxed and motivated coach and "I am a club and group man." He respects and accepts all players, employee, and staff that are around him. He perceived the psychological aspect as a major and very important factor that assist the player to do more and to win. In one of his recent interviews (Realmadrid, 2010) which was published in the official web site of Real Madrid Mourinho emphasized that "Winning is my main objective!"

Individual sport coverage receives minimum attention from the sport media. Only coaches of star athletes were interviewed after unique achievements such as Olympic medal and world championships. We found in our study that a coach in individual sport is familiar with innovative methods and use them in daily training practice. Moreover, they better apply recovery means and knowledge in biomechanics in training process.

Case 3: Jack Tupper Daniels, a former professor of physical education and cross-country running coach at State University of new York at Cortland, 
was named "The World's Best Coach" in cross country by the Runner's World Magazine (Press Release, 2005). The media characterizes him as a man who uses scientific methods in his work with athletes. His "training laboratory" included examination of the performance of elite middle and long distance runners and their VO2 max. Based on the results Daniels developed aerobic profiles for each athlete. He labeled these "pseudo VO2max" as "effective VO2max" values, VDOT values. According to Daniels, VDOT is a shortened form of VO2max, properly stated as "V-dot-O2max". With the result of a recent competition, a runner can find his or her VDOT value and determine an "equivalent performance" at a different race distance. Given that runners with identical VO2max values may have differences in running economy/efficiency, biomechanics, and mental toughness. Daniels concluded that VDOT, due to his holistic view, is a better value from which to assess fitness and determine training pace. Daniels divided his training method into six components, each of them require specific training intensity to improve. This approach indicates on Daniels's concern and involvement in his athlete's life.

Case 4: Another example from individual sport is Bob Bowman, an American swimming coach, who works with Michael Phelps. At the 2004 Games, Bowman helped Phelps to achieve eight medals, including six gold medals and two bronze. At the 2008 Beijing Olympics, he coached Michael Phelps to achieve 8 Olympic Gold Medals, which has never been done before in a single Olympics. Bowman was chosen on the $7^{\text {th }}$ place out of the best 50 coaches in the history of sports by the "Sporting News" (DeVault, 2009). Bowman graduated from Florida State with a Bachelor of Science degree in developmental psychology and studied classical music composition. According to the media he liked Prokofiev's $3^{\text {rd }}$ Piano concert because Prokofiev' music has structure, melodic and sarcastic elements (Valkenburg, 2008). The media characterizes Bowman as an individual that even in his life and habits outside of sport he reveals strong motivation and obligation to his goals. Bowman demands the same from his athletes.

The media describes the 12 years relationship between Bowman and Phelps as unique due to the cooperation and loyalty that they have for each other. For example, during their 12-year relationship, one of the longest partnerships in swimming, Phelps followed Bowman everytime he moved, celebrated holidays together, and shared emotional moments together: "Doesn't usually happen to me" Bowman said when he started to cry after he saw tears in Phelps eyes when setting a world record in the 400-meter individual medley (Valkenburg, 2008).

Case 5: The last example from individual sport is Glen Mills, sprinting athletic coach from Jamaica who from 2004 coaches Usain Bolt, the Olympic 
champion (six gold medals) and the fastest man on earth in 100 and 200 meters (eight gold medals in World Championship). In his early years, Mills was known as a prominent coach in the Jamaican athletics scene. He worked on improving his coaching style and earned a diploma from the International Olympic Committee training center in Mexico and a qualification in High-Level Spring Tech training at the IAAF Training Centre in Puerto Rico (Jamaica Gleaner, 2006).

While coaching Bolt, Mills emphasized on improving Bolt's technique, particularly on a more efficient stride frequency and better balancing (Rowbottom, 2008). The uniqueness of the relationship between Mills and Bolt can be seen from an interview with Bolt who praised Mills, saying it was his coaching which made him improve, not only as an athlete, but also as a person (Jamaica Gleaner, 2008). Mills focused on his training not only on the physical aspect but also on education and developing mental skills. For example, in one of the interview (Bradley, 2009) he referred to the importance of imagery skills "If you are nervous, you visualize failure. If you visualize winning, you have fun". To keep on high motivation and adherence Mills emphasized throughout the training process that "it is important to educate him (Bolt) about the journey rather than the final destination". We think that the core of the relationship between the two can be seen by Bolt's citation "The first thing he told me was that you have to lose before you can win" (Bradely, 2009).

\section{Summary}

The areas of science and media can supplement and enrich each other. In our research, we found differences in the profiles of team and individual coach. Best team sport coach focuses more on tactical and psychological preparation, team building, goal settings, cohesion, and management in sport. On the other hand, best individual sport coach focuses more on theory and methodology of sport training and psychological preparation such as motivation, goal setting, self-confidence and mental recovery. The media support the science data and add the emotional side and life stories of the coach, especially of the team sport coach. It is important that scientists and media people will recognize the potential for cooperation. The media should popularize research findings to ensure that the knowledge will be useful for daily work. Scientists should conduct more studies on the impact and influence of the media on coaches' and athletes' life and achievements. 


\section{References}

Bloom, G.A. (2002). Coaching demands and responsibilities of expert coaches. In J.M. Silva and D.E. Stevens (Eds.). Psychological foundations of sport. Allyn \& Bacon, Boston: MA.

Blumenstein, B., \& Orbach, I. (2010). The profile of the professional coach. Applied Research in Coaching and Athletics Annual, 25, 213-230.

Blumenstein, B., Orbach, I., Bar-Eli M., Dreshman, R., \& Weinstein, Y. (2012) High-level coaches' perceptions of their professional knowledge, skills, and characteristics. Sport Science Review, 21, 5-27.

Bradely S. (2009, July 7). "Lightning Bolt” illuminates business leaders. Swissinfo. ch. Retrieved from http://www.swissinfo.ch/eng/Home/Archive/ Lightning_Bolt_illuminates_business_leaders.html?cid=64018

Coaching Association of Canada (2005). Summary of the NCCP evaluation project, www.coach.ca/eng/certification/documents/REP_Summary_ NCCPEvalBlueprint_dc05.pdf

Cowley, J. (2005, December, 19). NS man of the year - Jose Mourinho. NewStatesman. Retrieved from http://www.newstatesman.com/200512190026

Cratty, B. (1973). Psychology in contemporary sport. Prentice hall, England clitts, NJ.

DeVault R.C. (2009). Sporting news top 50 coaches in history of sports. Sport. Retrieved from http://www.associatedcontent.com/article/2003698/ sporting_news_top_50_coaches_in_history.html?cat=14

Escarti, A. \& Guzman, J. (1999). Effects of feedback on self-efficacy, performance, and choice on an athletic task. Journal of Applied Sport Psychology, 11, 83-96.

European Coaching Council (2006). Review of the EU 5-level structure for the recognition of coaching qualifications. Consultation document version 3 .

Gilbert, W.D., Cote, J., \& Mallett, C. (2006). Developmental paths and activities of successful sport coaches. International Journal of Sport Sciences and Coaching, 1, 69-76.

Gilbert, W.D., \& Trudel, P. (2004). Analysis of coaching science research published from 1970-2001. Research Quarterly for Exercise and Sport, 75, 388-399. 
Hawkey, I. (2004, May 9). The big feature: Jose Mourinho. The Sunday Times. Retrieved from http://www.timesonline.co.uk/tol/sport/football/ article434404.ece

Hendry, L.B., \& Love, J.G. (1996). Scotland. In P. De Knop, L-M. Engstrom, B. Skirstad \& M.R. Weiss (eds.), Worldwide trends in youth sport (pp. 204221). Champaign, IL: Human Kinetics.

Henschen, K., \& Cook, D. (2003). Working with professional basketball players. In R. Lidor and Henschen, K.P. (Eds.) The psychology of team sports (pp. 143160). Morgantown, WV: Fitness Information Technology.

Jackson, P. (n.d.). Retrieved from http://www.nba.com/coachfile/phil_jackson/

Jackson, P. (n.d.). In Wikipedia online. Retrieved from http://en.wikipedia.org/wiki/Phil_Jackson

Jamaica Gleaner (2006, December 19). Gleaner editors' forum - top class coaches making the difference. Retrieved from http://www.jamaica-gleaner. com/gleaner/20061219/news/news1.html

Jamaica Gleaner (2008, August 25). Technique tweaks bolt Usain into history. Retrieved from http://www.jamaica-gleaner.com/gleaner/20080825/lead/ lead2.html

Martens, R. (1981). Sport personology. In G. Luschen \& G. Sage (Eds.). Handbook of social science of sport (pp. 492-508). Champaign, IL: Stipes.

Martens, R. (2004). Successful coaching. (3rd edition). Champaign, IL: Human Kinetics.

Mukoka, A. (2010, June 26). Italy coach Lippi takes responsibility for loss. The Post Online. Retrieved from http://www.postzambia.com/postread_ article.php?articleId $=10825$

Olderhove, H. (1996). Australia. In P. De Knop, L-M. Engstrom, B. Skirstad \& M.R. Weiss (eds.), Worldwide trends in youth sport (pp. 245-259). Champaign, IL: Human Kinetics.

Press Release (2005, March 24). World's best coach joins center for high altitude training. Retrieved from http://www.hastc.nau.edu/events-pressrm-032405. asp 
Press Release (2007, April 2). Jackson and Williams lead HOF class.

RealGM Basketball. Retrieved from http://www.realgm.com/src_wiretap_ archives/45442/20070402/jackson_and_williams_lead_hof_class/\#

Realmadrid (2010, August 9). Winning is my main objective. Retrieved from http://www.realmadrid.com/cs/Satellite/en/1330006501110/noticia/ Entrevista/_This_is_the_best_thing_that_can_happen_.htm

Reheuser, R. (2001). Lue and Behold. NBA Finals 2001. Retrieved from http:// www.nba.com/finals2001/lue_lakers_010608.html?nav=ArticleList

Rowbottom, M. (2008, August 4). Bolt from the blue. The Independent. Retrieved from http://www.independent.co.uk/sport/olympics/bolt-from-theblue-883180.html

Schneider, R.C., \& Stier, W.F. (2008). Attributes and competencies sought in physical education teachers/coaches - a national survey of secondary school principals. Applied Research in Coaching and Athletics Annual, 23, 194-212.

Smith, R., \& Smoll, F. (2005). Assessing psychosocial outcomes in coach training programs. In D. Hackford, D. Duda, \& R. Lidor (Eds.). Handbook of research in applied sport and exercise psychology: International perspectives (pp. 293-316). Morgantown, WV: Fitness Information Tech.

Sport Coach UK (2007). United Kingdom Coaching Certificate impact study:

Definitional, conceptual and methodological review. John Lyle consulting.

The Daily Telegraph (2008, April 8). Barcelona v Inter Milan: Jose Mourinho 'best manager in the world', says Pep Guardiola. Telegraph.co.uk. Retrieved from http://www.telegraph.co.uk/sport/football/competitions/championsleague/7643868/Barcelona-v-Inter-Milan-Jose-Mourinho-best-manager-inthe-world-says-Pep-Guardiola.html

Valkenburg, K.V. (2008, August 16). Opposites attract. Ravens Report. Retrieved from http://www.baltimoresun.com/sports/bal-te. sp.bowman16aug16,0,265609.story

Vealey, R.S. (1989). Sport personology: A paradigmatic and methodological analysis. Journal of Sport \& Exercise Psychology, 11, 216-235.

Vealey, R.S. (1992). Personality and sport: A comprehensive view. In T.S. Horn (Ed.), Advances in sport psychology (pp. 25-59), Champaign, IL: Human Kinetics. 


\section{Yamaguchi, Y. (1996). Japan. In P. De Knop, L-M. Engstrom, B. Skirstad \&} M.R. Weiss (eds.), Worldwide trends in youth sport (pp. 67-75). Champaign, IL: Human Kinetics.

Dr. Boris BLUMENSTEIN is an associate professor in Givat Washington Academic College and the Director of the Department of Behavioral Sciences at the Ribstein Center for Sport Medicine Sciences and Research, Wingate Institute, Israel. His research focuses on the mental skills training for enhanced performance, stressperformance relationships, the effectiveness of different mental interventions, and athletic competition readiness. He has published six books, 20 book chapters and approximately 80 refereed journal articles.

\section{Corresponding address:}

Prof. Boris Blumenstein

Ribstein Center for Sport Medicine Sciences and Research

Wingate Institute

Netanya 42902, Israel

Fax: +972-9-8639412

E-mail: borisb@wingate.org.i

Dr. Iris ORBACH is a researcher and a sport psychology consultant in the Department of Behavioral Sciences at the Ribstein Center for Sport Medicine Sciences and Research, Wingate Institute, Israel. In addition to teaching, Dr. Orbach has published two books and numerous articles and book chapters. Her current research interests include stressperformance relationships, children and motivation in sport, and the effectiveness of various mental training practices. Dr. Orbach uses her psychology skills as a consultant for athletes at all skill levels. 
